\title{
Venture Capital As An Alternative Funding For Micro, Small and Medium Enterprises (UMKM) In Medan
}

\section{Zulfi Chairi}

Faculty of Law, University of Sumatera Utara Author's email zulfi@usu.ac.id

\section{Afrita}

Faculty of Law, University of Sumatera Utara

Author's email afrita@usu.ac.id

\section{Eko Yudhistira}

Faculty of Law, University of Sumatera Utara

Author`s email eko.yudhistira@usu.ac.id

DOI: $10.23917 /$ jjr.v9i2.9020

Submission
Track:
Received:
11 Oktober 2019
Final Revision:
13 Desember 2019
Available online:
17 Januari 2020
Corresponding
Author:
Zulfi Chairi
zulfi@usu.ac.id

Submission Track:

\section{ABSTRACT}

Purpose of the study: The purpose of this study is to know the regulation about UMKM empowerment through venture capital funding in Medan and how the deal between the venture capital institution and UMKM.

Methodology: This study is using the descriptive research methodology and using the primary and secondary data.

Results: The study give the explanation about how the deal and the legal protection to the Micro, Small and Medium Enterprises which use the Venture capital funding system in Medan.

Applications of this study: This study can be used as a reference to the venture capital company in Medan, The OJK, and Indonesian Government to revise and change the regulation regarding venture capital funding system so the regulation can accommodate and help the Micro, Small and Medium Enterprises in Medan.

Novelty/Originality of this study: There is no research about the venture capital funding which help the MSME in Medan before. This situation become a chance to do a study regarding the regulation and legal protection in the funding process to help the MSME empowerment in Medan.

Keywords: MSME, Funding, Venture Capital 


\section{INTRODUCTION}

Micro, small and medium enterprises or called UMKM is a group of enterprises which is important for the economy of Medan. That's because UMKM is a business sector which has the biggest number with the significant role to absorb man power to increase the PDB of society. It becomes an activator of area development and economy establishment. UMKM sector has a big marketplace because there will always a marketplace for their product or services. That's because UMKM is the producer of goods and services for the middle to law class society with low purchasing capacity. The other reason is UMKM able to survive in crisis because the capital is from their own (Bagus Ardiyanto, 2013).

The important role of UMKM has motivate a lot of countries included Indonesia to develop the existence of UMKM. At least there are three reasons why UMKM is important for developing states. First because the performance of UMKM is better to create productive man power. Second, as a part from its dynamics, UMKM often reach productivity excalation through investment and technology changes. Third, because UMKM has superiority in flexibility rather than the big enterprises.

Data from Department of National Plan Development, Centre Statistic Development and United Nation Population Fund predict the number of UMKM in Indonesia in 2018 is 58,97 million people, while the Ministry of Cooperation and UMKM stated there are more than 58,91 million unit of micro enterprises, 59.260 million unit of small enterprises and 4.987 million unit of big enterprises (Rencana Strategis Kementrian Koperasi dan Usaha Kecil dan Menengah Republik Indonesia, Jakarta, 2012, hal.17).

In Sumatera Utara there are more than 2,8 million UMKM but the registered one in Department of Cooperation and UMKM is less than $20 \%$ or about 380 thousand. There are a lot of UMKM which not being registered well. In this situation the government of Medan has commitment to develop the UMKM by empowering the UMKM. The important step to empower it is by opening the chance to increase the quality of man power.

One of the law certainty which regulate the economic activity is certainty to regulate the venture capital fund institution as one of funding institution for the UMKM, also as new funding institution outside the bank. The Venture Capital enterprises is a platform and distributor where the investor who has money want to distribute their money to the one who need it. Venture capital enterprise which run investment business to business partner is the party who can give training and mentoring in administrative, accountancy, management, 
marketing and other sector which support the activity of venture capital enterprise. In Indonesia venture capital is hoped to be able to develop in order to empower the micro, small and medium enterprises which often facing the funding obstacles. The problem is the imbalance between big entrepreneur who get support from the government with the small entrepreneur who don't get that support. Moreover time by time UMKM cannot fulfill the economic and politic requirement as the result of the rise of some banks which only being misused by the big entrepreneur and government who able to fulfill the bankable requirement, while the small entrepreneur still unable to use the existed bank institution.

The crucial problem which is faced by the UMKM is the limited access to the UMKM to the productive resources such as the capital, technology, information and marketplace. That limited access caused the obstacles to improve the capacity of the company and develop their products to have competitiveness. UMKM capital access problem caused because the limit of UMKM itself in marketing, technology mastering and information, also bad management problem. Those factors caused a low trust from the bank institution and other funding institution to give loan and capital to UMKM. Furthermore, the un-capability of UMKM to provide collateral make them unable to accessed credit from bank. If UMKM as the form of people`s economy is not given access and not being empowered, it will have no ability to compete the power of global economy.

The limited capital and permission problem make UMKM in Medan unable to develop. Less information and entrepreneurship competition caused low business productivity and human resources. This becomes one of the obstacles of UMKM to develop in a state economic. It seen from the un-capability of UMKM seller in managing their enterprise. The lack of information which known by the UMKM entrepreneur about the Venture Capital Company as one of funding alternative. This research also become one of the suggestion for the funding institution especially the venture capital in its existence in funding business to help UMKM in Medan.

Venture Capital funding have to be preceded by an agreement. The presence of multiple form of enterprises of the business partner will effect to the pattern of legal relationship. The matter of the collateral in venture capital funding also have to be noticed in order to bring the UMKM empowerment. Regulations about the existence of venture capital with its connection to the UMKM empowerment is also not really good yet. 
Based the explanation above the existence and role of the funding institution venture capital in Indonesia is important to be examined. It because that's a new rise institution which has impact to the business world development and the legal world. Unfortunately this institution is not followed with the legal regulation which regulate the operational and legal relation between the venture capital company with the funded company.

\section{RESEARCH METHOD}

This legal research has normative empiric typology research. The normative empiric legal research (applied) examines the implementation of positive law in the factual legal phenomenon. The study is purposed to make sure whether the implementation of positive law in concreto is suitable with the act substance. This normative empiric legal research is divided into 2 stages. The first stage is to examine the regulations and see its implementation. The second stage is to see how the implementation of the regulation in the real life.

This research is taking place in Medan, Sumatera Utara which is considered of 21 subregion and has large number of MSME. The research is done by doing deep and direct interview and collect the data from PT. Sarana Sumut Ventura.

\section{RESULTS \&DISCUSSION}

\section{A. LEGAL REGULATION ANALYSIS TO THE ESTABLISHMENT OF UMKM THROUGH THE ALTERNATIVE EMPOWERMENT VENTURE CAPITAL IN MEDAN}

\section{A.1. Philosophical Based Of UMKM Empowerment.}

In Indonesia, the definition of UMKM is regulated in Act of Indonesia Number 20 of 2008 about UMKM. In this regulation, the criteria which is used to define UMKM in article 6 is the value of net worth or the value of assets not including land and buildings for the place of business, or annual proceeds. For micro businesses, assets have a maximum of Rp.50 million excluding land and buildings where the business has the highest annual sales results of Rp300 million, small businesses have assets of more than Rp.50 million to a maximum of Rp.500 million excluding land and buildings where the business has annual sales of more than Rp.300 million to a maximum of Rp.2,5 billion while medium-sized businesses are companies with a net worth of more than Rp.500 million to a maximum of Rp.100 billion from annual sales above Rp.2.5 billion to a 
maximum of Rp.50 billion (Tulus,2009). In addition to using monetary values as a criterion, some government agencies such as the Ministry of Industry and the Central Statistics Agency (BPS), so far have also used the number of workers as a measure to differentiate business scales between micro, small, medium and large businesses. For example, according to the National Statistics Agency (BPS), micro businesses are business units with a total of 4 permanent workers, small businesses of 5 to 19 workers, and medium businesses from 20 to 99 people. Companies with more than 99 employees are included in the large business class. In Medan itself, the many types of UMKM that exist are feeling to be very supportive of people's lives, especially the lower middle class. Based on data obtained through the Office of Cooperatives and UMKM in Medan, the number of types of businesses that have been registered are as follow:

\begin{tabular}{|c|c|c|c|c|}
\hline Period & $\begin{array}{c}\text { Micro } \\
\text { Sized } \\
\text { Enterprises }\end{array}$ & $\begin{array}{c}\text { Small } \\
\text { Sized } \\
\text { Enterprises }\end{array}$ & $\begin{array}{c}\text { Medium } \\
\text { Sized } \\
\text { Enterprises }\end{array}$ & $\begin{array}{c}\text { Total types of } \\
\text { UMKM in } \\
\text { Medan }\end{array}$ \\
\hline December 2018 & 734 & 110 & 11 & 855 \\
\hline
\end{tabular}

Table.1 Data of Number of Types of UMKM in Medan

Based on these data UMKM activities in the city of Medan must be accommodated as best as possible because many residents depend on these activities. The existence of UMKM has been proven to have influenced the community's economy, therefore the existence of UMKM must be empowered by the government. In practice, UMKM actors, especially micro and small businesses, often have difficulty accessing capital because these businesses have not yet been assessed as bankable to get capital loans. Empowerment of UMKM through venture capital financing alternatives is based on the opening of the 1945 Constitution that one of the goals of an independent Indonesian nation is to advance public welfare, meaning that it is not only for a part of the community so that the government is fully responsible for working on a system that fulfills this goal. This is also included again in the articles in the 1945 Constitution, articles 33 and 34 where the state develops a social security system for all people and empowers weak and 
incapable people in accordance with human dignity, furthermore the further provisions regarding the implementation of the article are regulated in the law invite. In this case the provisions of UMKM empowerment are regulated in Act Number 20 of 2008 about UMKM consisting of 11 chapters, 44 articles, and 45 paragraphs. Basically, this lawaims to: In general, the goals or targets to get are the realization of strong and independent UMKM that have high competitiveness and play a major role in the production and distribution of basic needs, raw materials, and in capital to face free competition.

Through this Act the government is expected to take steps that are solution and applicable in empowering community businesses. Mahidin said that empowerment can be interpreted as an effort to improve the ability of a person or group so that they are able to carry out their duties and authorities as the task demands performance. Empowerment is a process that can be done through various efforts, such as giving authority, increasing participation, giving trust so that each person or group can understand what will be done, which in turn will have implications for increasing the achievement of goals effectively and efficiently. The concept of empowerment carried out aims in the economic and social fields empowerment, with the intention of the target group can manage its business, then market and form a marketing cycle which is relatively stable and so that the target group can carry out its social functions in accordance with its social roles and tasks. Community empowerment is a basic element that enables a community survive and in a dynamic sense develop themselves and achieve progress. Community empowerment itself becomes the source of what in political insight is called national resilience. This means that if people have high economic capacity, then it is part of national economic resilience (Rukminto, 2008).

\section{A.2. Legal Based Of UMKM Empowerment Through Venture Capital}

The Empowerment of UMKM by the government means that the government is trying its best to overcome the obstacles faced by UMKM and also bridge the needs needed by UMKM to develop. The main problem faced by micro and small business actors is the difficulty in accessing capital. Bank financing institutions generally do not give access to businesses that are not yet bankable. Therefore, as a follow-up to community empowerment as mandated by the 1945 Constitution, financial institutions are regulated in 
Presidential Decree No. 61 of 1988 concerning Financing Institutions and Minister of Finance Decree No. 1251 / KMK.013 / 1988 concerning Provisions and Procedures for the Implementation of Financing Institutions. The meaning of financing institutions according to Article 1 number (2) Presidential Decree No. 61 of 1988 concerning Financing Institutions, is a business entity that carries out financing activities in the form of providing funds or capital goods without withdrawing funds directly from the public. From the above understanding there are several elements, such as:

1. Business entities, namely finance companies that are specifically established to carry out activities which are included in the business of financial institutions;

2. Financing activities, i.e. conducting activities or activities by way of financing to parties or business sectors that need them;

3. Provision of funds, namely the act of providing fund for a purpose;

4. Capital, goods, namely goods used to produce something;

5. Not withdrawing funds directly;

6. Society, i.e. a number of people who live together in a place.

In addition, according to Presidential Regulation Number 9 of 2009 about Financing Institutions, a Financing Institution is a business entity that carries out financing activities in the form of providing funds or capital goods. Based on Presidential Decree Number 61 of 1998 and Minister of Finance Decree Number 1251 / KMK.013 / 1988, venture capital activities are included in the activities of financial institutions, but venture capital activities are based on Decree of the Minister of Finance No. 468 / KMK.017 / 1995 dated 03 October 1995 was no longer included in the activities of financial institutions. This is confirmed by the obligation to choose whether a finance company will become a finance company or become a venture capital company. The existence of these provisions, then venture capital activities are no longer one of the activities of financial institutions. Like other financial institutions, venture capital institutions are also regulated in various regulations which are the legal basis, among others:

1. Presidential Decree Number 61 of 1988 about Funding Institutions. In this provision it is stated that venture capital is recognized as a model of financing distribution. In the decision determined that the venture capital company is a business entity that 
carries out financing business in the form of equity participation in a company that receives financing help for a certain period. The legal form of a venture capital company is a Limited Liability Company or Cooperative. Venture capital company shares can be owned by Indonesian citizens and / or Indonesian legal entities (joint ventures). Share ownership by a foreign business entity is determined at a most of $85 \%$ of paid up capital. Venture capital companies are prohibited from withdrawing funds directly from the public in the form of Current Accounts, Deposits, Savings, Promissory Notes, but can issue promissory notes only as collateral for debts to banks that are creditors.

2. Decree of the Minister of Finance Number 1251 / KMK.013 / 1988 about Provisions and Procedures for the Implementation of Financing Institutions. This regulation is a further implementation of financial institutions as it has been called Presidential Decree Number 61 of 1988. Then the decision Revised and refined by Decree of the Minister of Finance Number 468 of 1995. In a decision of the Minister of Finance it was stated, the financial institution carries out activities which include capital businesses venture, venture capital activities carried out in the form of equity participation in a business partner company to:

a. Development of a new innovation;

b. Development of a company in their beginning which has financial capital problem;

c. Help the company which in development period;

d. Help the company which in deterioration period;

e. Development of research and engineer project;

f. Development of new technology and technology expert, from inside or outside of the country;

g. Help the transfer ownership of the company. Equity participation in each company business partnership is temporary and may not exceed 10 years. Withdrawal of equity participation by a venture capital company in all its forms, is reported to the Minister of Finance no later than 3 (three) months after it is implemented. Before conducting business activities, venture capital companies must get a business license from the Minister of Finance. Business license is given no later than 30 (thirty) working days from when the 
application is received in full. Business licenses are valid as long as the venture capital company is still running its business. There is no charge for granting business licenses. Venture capital companies must clearly state their Articles of Association for their financing activities. The amount of paid-up capital or principal savings and mandatory savings for venture capital companies is determined as follows:

a. National Private Companies of at least Rp. 10,000,000,000 (ten billion rupiah);

b. Indonesian and foreign joint venture companies of at least $\mathrm{Rp}$. 25,000,000,000 (twenty five billion rupiah);

c. Cooperatives of at least $\mathrm{Rp} 5,000,000,000$ (five billion rupiah). Development and supervision of venture capital companies are carried out by the Minister of Finance. Supervision is carried out by the Ministry of Finance and is assisted by Bank Indonesia which is regulated by a joint decree. Finance companies that obtain business licenses for more than one financing activity are required to choose to become another finance company or venture capital company. Financing companies that have chosen to become venture capital companies are prohibited from conducting Leasing, Factoring, Credit Card, and Consumer Financing transactions. Venture capital companies that conduct financing activities that are contrary to the provisions in this decree are terminated or revoked their business licenses. Termination of activities or revocation of business license after:

a) A written warning is given to the person concerned 3 (three) times in a row with a grace period of 1 (one) month;

b) The activity or business permit is suspended for 6 (six) months since the last warning. If prior to the end of the freezing period, repairs have been made, the business activity or permit will be reinstated. However, if until the end of the freezing period there is also no improvement, the activity is stopped or the business license is revoked. 
3. The Act Number 10 of 1998 about Bank in its principle the venture capital activity is no included to bank business. But incidentally and in certain cases, namely in the case of non-performing loans, banks are justified to include their capital in the debtor company with the stipulation that until the time the bank has to withdraw its equity participation. So it is indeed similar to venture capital activities.

4. Government Regulation Number 18 of 1973 is the base of first Venture Capital establishment in Indonesia, PT Bahasa Pembina Usaha Indonesia (BAHANA), which its capital is hold by Department of Finance and The Bank of Indonesia. Thus, Government Regulation Number 18 of 1973 is also one of the legal base and historical pillar of the establishment of Venture Capital Company in Indonesia;

5. The Act Number 40 of 2007 about Limited Liability Companies, because a venture capital company is a legal entity that can be a Limited Liability Company or a Company whose capital is divided into shares, then the form of equity participation in a business partner company is carried out by investing in stock purchases. If the business partner company agrees to develop the company by cooperating with a venture capital company in the form of equity participation, both in the form of purchase of existing shares or in the form of more company capital, this means the venture capital company deposits a sum of money as the price of the shares to be controlled. If this capital investment is carried out through the purchase of most of the shares of a business partner company, the provisions about the transfer of shares will apply, which of course must have the approval of the RUPS.

Beside of the Act Number 40 of 2007, occur the provisions which regulate the private side in these legal regulations below:

1. The Act Number 19 of 2003 about BUMN and its implementation regulation. The Act is valid if the form of the Venture Capital is a company.

2. The Act Number 8 of 1995 about capital market. The act valid if the Venture Capital company do trading in the capital market;

3. The Act Number 25 of 1992 about Cooperatives Article 41 states that cooperative capital consists of own capital and loan capital. Own capital can come from members, other cooperatives and or their members, banks and other financial institutions, the issuance of bonds from other debt securities, other legal sources. 
Article 42 of the same law states that, in addition to the capital as referred to in Article 41, cooperatives can also carry out capital fertilization originating from participation capital. Participation capital is that capital accumulation from participation capital, both sourced from the government and from the community, is carried out in the context of strengthening cooperative business activities, especially in the form of investment. Participation capital also bears the risk, the owner of the investment capital does not have voting rights in the Member Meeting and in determining the overall cooperative policy. However, owners of investment capital can take part in the management and supervision of investment businesses supported by their investment capital by the agreement.

4. The Act Number 5 of 1960 about the main provisions of agrarian and its implementation regulations. This act is valid if the Venture Capital Company make an agreement which related to the rights of land.

5. The Act number 3 of 1982 about the have to registered company and its implementation regulation. This Act is valid if the venture capital company have a business with its registration, re-registration and liquidation registration of the company.

6. The Act Number 12 of 1995, Act number 7 of 1991, Act Number 8 of 1991, Act number 16 of 2009 and its implementation regulation. All is about tax. Those acts are valid because the venture capital oblige to pay tax of earth and building, incomes, and the addition of value and other types of tax. Based on that we can see that the venture capital legal base can be seen through the private, public and administrative law sectors.

Furthermore, venture capital funding is regulated more specific in the Regulation of Financial Services Authority:

1. Financial Services Authority Regulation Number 34/POJK.05/2015 about the business permission and venture capital company institution. The regulation regulate how the general provisions of venture capital company, the form of the company, business permission, capital, organization structure, Shariah venture capital, and how it will be dissolved, etc. 
2. Financial Services Authority Regulation Number 35/POJK.05/2015 about the run of venture capital business. The regulation regulate how the activity of venture capital entrepreneur and Shariah venture capital company, equity participation activity, business agreement, equity, financial capital resources, venture money, and venture capital business for uMKM. In chapter VII the regulation clearly regulate how the provision of venture capital for UMKM. In article 51 regulate how the minimum limitation for venture capital and Shariah venture capital company at least have $5 \%$ of business activity of venture capital or Shariah venture capital.

3. Financial Services Authority Regulation Number 36/POJK.05/2015 about Good Corporate Governance for venture capital enterprise. The regulation regulate how the implementation of good corporate governance, RUPS, investor, board of director and commissioner, Shariah board of trustees, yearly business plan, and etc.

4. Financial Services Authority Regulation Number 37/POJK.05/2015 about direct inspection of Venture Capital Company. The regulation regulate how the direct inspection, the follow-up for the result of direct inspection and sanction.

Based on the interview result with the PT. Sarana Sumut Ventura Medan, the existed legal regulation about venture capital is enough to accommodate the interest of business partner funding and venture capital enterprise in Sumatera Utara especially in Medan. Therefore, now the need it the regulation in several sub-area and sub-region.

\section{B. COOPERATION AGREEMENT ASPECT BETWEEN VENTURE CAPITAL FUNDING INSTITUTION WITH UMKM IN THE PATTERN OF BUSINESS PARTNER}

Concept Of Partnership In A Cooperation Agreement Between A Venture Capital Enterprise And UMKM Players. The concept of partnership is a translation of togetherness (partnership) or social responsibility for the environment in accordance with the concept of participatory management. Because under the participatory concept, large companies must also be responsible for developing small businesses and their customer communities because in the end the partnership concept that guarantees the existence of large companies, especially for the long-term. Partnership is a business strategy that is carried out by two or more parties in a certain time to do mutual benefits by mutual need 
and mutual encouragement. Because it is a business strategy, the success of a partnership is largely determined by the compliance between those who partner in carrying out business ethics. In an effort to realize a business partnership that is able to empower the people's economy, it is very necessary to have a clear role for each party involved in the partnership. Thus, it is expected to measure the extent to which the parties concerned have carried out their duties and roles well.The definition of partnership itself is based on Article 1 Number 13 of Act Number 20 Year 2008 jo Article 1 Number 4 of Government Regulation Number 17 of 2013 about Micro, Small and Medium Enterprises is cooperation in business relations, both directly and indirectly, on the basis of mutual principles requires, trusts, strengthens, and benefits that involve Micro, Small and Medium Enterprises with Big Business. The concept of partnership is formulated in Article 25 of Act Number 20 Year 2008 concerning Micro, Small and Medium Enterprises, including:

"The Government, Local Government, Business World, and the community help, support and stimulate partnership activities, which need each other, trust, strengthen and benefit."

Partnership between Micro, Small and Medium Enterprises and Partnership between Micro, Small and Medium Enterprises with Large Enterprises covers the process of skills transfer in the fields of production and processing, marketing, capital, human resources, and technology. The Minister and Technical Minister regulate the provision of incentives to Large Enterprises that conduct partnerships with Micro, Small and Medium Enterprises through innovation and development of export-oriented products, employment, use of proper and environmentally friendly technology, and organize education and training. From the concept of partnership, according to Article 7 of Law Number 20 Year 2008 concerning Micro, Small and Medium Enterprises, it is stated that the Government and Regional Governments can foster business situation by establish legal regulations and policy which cover several aspects such as, funding, facilities, business information, partnership, business permission, chance to do business, business promotion, institution support. The partnership agreement is stated in a written agreement that at least regulates the business activities, rights and obligations of each party, the form of development, the time, and the settlement of disputes. The partnership agreement in question must not conflict with the basic principle of independence of Micro, Small and Medium Enterprises 
and not create dependence of Micro, Small and Medium Enterprises on Large Enterprises. Likewise in the case of UMKM financing, micro and small businesses are considered not yet bankable to obtain loans from financial institutions in general, therefore venture capital companies are expected to play a role in assisting UMKM in terms of financing and others. Based on data obtained from PT. Means of North Sumatra Venture Capital Medan the number of UMKM fostered at PT. Sarana Sumatera Utara Medan Venture Capital Facilities are as follows:

\begin{tabular}{|c|c|c|c|}
\hline Period of Time & Reguler & $\begin{array}{c}\text { Group } \\
\text { Landing }\end{array}$ & Total of UMKM \\
\hline $\begin{array}{c}\text { December 2017- July } \\
2019\end{array}$ & 185 & 6.337 & 6.522 \\
\hline
\end{tabular}

Table 2. Number of UMKM supervised by PT. Sarana Sumut Ventura Medan

Based on these data, the number of UMKM under the guidance of PT. Sarana Sumut Ventura Medan are divided into debtors who get capital and personal (regular) coaching and debtors who get capital and coaching together (group landing). Group landing financing is the provision of credit to individuals who are members of a group so that they can have access that is incorporated in a program. Programs that are implemented are usually for the poor who do not have collateral to get credit. The majority of the group consists of women from PKK and Youth Organization. This group-based credit is made for individuals but all group members are responsible for the payment of the credit. Based on the obligations and responsibilities of joint loans, each member who does not experience difficulties can help pay for other members who are not experiencing difficulties. The measure of success of group loan programs can be seen from the rate of return. Positive benefits obtained if using a groupbased credit system with a joint liability lending financing scheme, among others, reduces the adverse selection problem, which when forming a group pays attention to credit worthiness to prevent high risk loans. In addition, it can reduce the problem of moral perversion in that each member supervises and monitors each other to make sure that members use credit funds for productive activities to guarantee credit payments. Provision of capital in a group landing at PT. Sarana Sumut Ventura Medan has 
a maximum limit of 20 million rupiah per group. The financing scheme is considered good enough to help small communities but the funding is difficult to access by people who live far away in the city of Medan because PT. Sarana Sumut Ventura Medan only domiciled in the City of Medan.

\section{UNSURE OF AGREEMENT IN PATTERN OF PARTNERSHIP BETWEEN VENTURE CAPITAL COMPANY AND THE UMKM PLAYERS}

Based on article 1313 Private Law Book, an agreement is an act with one or more person tied to one or more other people. From this phenomenon appear one relationship between those two individuals or more which called an engagement. An agreement issue an engagement between two individuals who made it. In its form, agreement is a series of words containing promises or abilities that are spoken or written. Thus, the relationship between an agreement and agreement, is that the agreement issued an agreement. Agreement, is the source of the agreement (J. Satrio, 1995) As mentioned in the old doctrine, which referred to as an agreement, is a legal act based on an agreement to cause legal consequences. In this definition we can see there is a consesualism principle and the emergence of legal consequences (growth or disappearance of rights and obligations), then according to the new doctrine put forward by Van Dunne in his book Salim H. S., an agreement is defined as a legal relationship between or more parties based on the agreement to cause legal consequences. From the above understanding, it seems that in an agreement that will lead to a legal relationship of the parties who made the agreement. Each party is bound to one another and creates rights and obligations between the parties who made the agreement. If an agreement is observed and elaborated further, then in an agreement there are elements which can be classified as follows:

a. There is the party who make the agreement

The intended party is that there must be at least two people, the parties acting as the subject of the agreement. The subject can consist of humans or legal entities. In the case of venture capital partners that are parties to the financing agreement are the Venture Capital Company (PMV) / Sharia Venture Capital Company (PMVS) and the business partner company in this case micro, small and medium business actors. 
b. There is the agreement from every party

The parties before making an agreement or in making an agreement must be given both, this can be called the principle of consensual of an agreement. Consensus must exist without coercion, deception, and doubt. In this case the Venture Capital Company (PMV) and the business competition company agree on their respective rights and obligations without any element of coercion either directly or indirectly, deception or doubt.

c. There is a purposed to be achieved

An agreement must have one or some goals which it want to achieve and with that agreement those purposes or with the presence of the agreement the purposes can be achieved. In this case they as the subject of the agreement which make them as the goal of the run of venture capital investment accordance to article 9 paragraph 2 Financial Services Authority Regulation Number 35/POJK.05/2015, which stated:

i. Development of a new discovery

ii. Development of a company or business of people who in the first stages of their business are experiencing financial difficulties

iii. Development of micro, small, medium and cooperative businesses

iv. Assist each company or businesses that are in the development stage or stage of business decline.

v. Take over the company or business of people who are at the stage of development or stage of business decline.

vi. Development of research and engineering projects

vii. Development of various uses of new technology and technology transfer both from domestic and abroad; and / or

viii. Assist in transferring company ownership

d. Contract carried out by every parties to the agreement have certain rights and obligations, which contradict each other. If one party with another, it is a right and vice versa. In the partnership pattern between a Venture Capital Company and a Business Partner Company, in this case MSME actors are regulated in matters of their 
respective achievements such as a Venture Capital Company must provide funds, help manage the company and so on while the Business Partner Company is required to pay credit, conduct business well and so on. Venture Capital Companies and Business Partner Companies then also apply the principle of profit sharing in accordance with mutual agreement. (Article 22 of OJK Regulation No. 35 / POJK.05 / 2015)

e. There are certain conditions. The contents of the agreement must contain certain conditions, because in the agreement according to the provisions of Article 1338 paragraph (1) of the Civil Code it states that an agreement made legally applies as a law for those who make it. In this case based on Article 27 of Financial Services Authority Regulation No. 35 / POJK.05 / 2015 agreement of business activities carried out between a Venture Capital Company and a Business Partner Company at least regulates:

1) Types of business

2) Number and date of the agreement

3) Identity of the parties

4) Total of equity participation and/or the financial financing

5) Deadline of the equity and financial participation

6) Level of payback (if any)

7) Object of collateral (if any)

8) Details of cost related with the participation/financing which at least contains :

i. Survey cost (if any)

ii. Provision Cost (if any)

iii. Public Notary cost (if any)

iv. Agreement cost (if any)

9) Provisions about rights and responsibility of the parties

10) Provisions about fined (if any)

11) Mechanism if there is a dispute and the solution option for the dispute.

f. There is a specific form 
Agreement based on the form can be made written or not written, in certain situation the agreement is made written in a form of an authentic contract or the not authentic one. In financial capital funding matter the one which becomes main unsure of the agreement need to be written (article 26 Financial Services Authority Regulation Number 35/POJK.05/2015).

In every financing business activity, including venture capital, the initiative to enter into contractual relations comes from parties, especially the investee company. Thus, the will of the parties who are the source of the law, wishes of the parties are set forth in written form in the form of an agreement stipulating the rights and obligations of each party in the venture capital financing business and only applies as long as the parties do not specify otherwise specifically in the agreement made.

\section{CONCLUSION}

Philosophically, the protection of UMKM empowerment is protected by a constitution which is one of the goals of the Indonesian state in opening the 1945 Constitution of the Republic of Indonesia is to advance public welfare. The mandate was then confirmed through the regulations below such as Law Number 20 of 2008 about UMKM, Presidential Decree Number 61 of 1998 and Minister of Finance Decree Number 1251 / KMK.013 / 198, Presidential Decree Number 61 of 1988 about Financial Institutions and more more detail is regulated in OJK Regulation Number 34 / POJK.05 / 2015 about Business Licensing and Institutional Venture Capital Companies, OJK Regulation Number 35 / POJK.05 / 2015 about Operation of Venture Capital Business, OJK Regulation Number 36 / POJK.05 / 2015 about Good Corporate Governance for Venture Capital Companies, OJK Regulation Number 37 / POJK.05 / 2015 about Direct Investments in Venture Capital Companies.

The financing agreement entered into by PT Sarana Sumut Ventura Medan with the Business Partner Company in this case UMKM principals have basically fulfilled all aspects of the agreement such as the parties agreeing, the agreement between the parties without coercion, deception or doubt, the existence the goals to be achieved from the agreement, the achievements to be carried out by each party, the existence of certain conditions and the shape of the agreement. 


\section{ACKNOWLEDGEMENT}

The research was funding by the Direktorat Riset dan Pengabdian Masyarakat Direktorat Jenderal Penguatan Riset dan Pengembangan Kemenristekdikti (Directorate of Research and Community Service Directorate General of Research and Development Strengthening Ministry of Research, Technology and High Education of Indonesia) 2019 budget year. The research team also thank the Lembaga Penelitian Universitas Sumatera Utara (Research Department of Universitas Sumatera Utara) and all actor who has support this research.

\section{REFERENCES}

\section{Book}

Sjahrir, Persoalan Ekonomi Indonesia: Moneter. Perkreditan dan Neraca Pembayaran, Jakarta: Pustaka Sinar Harapan, 1995.

Ardiyanto,Bagus. Analisis Bantuan Kredit Dari Program Kemitraan Dan Bina Lingkungan (Pkbl)Pt. Pelabuhan Indonesia III (Persero) Cabang Tanjung Emas Semarang Terhadap Perkembangan Usaha Mikro KecilDi Kota Semarang, Semarang hal. 1-59: Universitas Diponegoro,2013.

Isbandi Rukminto,Intervensi Komunitas Pengembangan Masyarakat sebagai Upaya Pemberdayaan Masyarakat, Jakarta: PT. Raja Grafindo Persada, 2008.

Tulus Tambunan, UMKM di Indonesia, Bogor: Ghalia Indonesia, 2009.

Tulus Tambunan, Usaha Mikro Kecil dan Menengah di Indonesia: Isu-Isu Penting, Jakarta: LP3ES, 2012.

Muhammad Djumhaha, Hukum Perbankan di Indonesia, Bandung: PT. Citra Aditya Bakti, 1998.

Munir Fuady, Hukum Tentang Pembiayaan (Dalam Teori dan Praktek), Bandung: PT. Citra Aditya Bakti, 2006.

Abdulkadir Muhammad, Rilda Murniati, Segi Hukum Lembaga Keuangan dan Pembiayaan, Bandung: Citra Aditya Bakti, 2000.

Hassanudin Rahman, Segi-segi Hukum \& Manajemen Modal, Bandung: PT. Citra Aditya Bakti, 2003.

Hasanuddin Rahman, Segi-segi Hukum dan Manajemen Modal Ventura serta pemikiran alternatif kearah modal-modal ventura yang sesuai dengan kultur bisnis di Indonesia, Bandung: PT. Citra Aditya Bakti, Bandung, 2003.

Robbia Pancarasa, Mencari Bentuk Usaha Modal, (Harian Bisnis Indonesia, 4 September 1991)

J. Satrio, Hukum Perikatan, Perikatan yang Lahir dari Perjanjian, Buku II,Bandung: PT Citra Aditya Bakti, 1950.

\section{Government Regulation}

Peraturan Menteri Keuangan Nomor 18/PMK.010/2012 tentang Perusahaan Modal Ventura 
Undang-undang Nomor 20 Tahun 2008 tentang Usaha Mikro, Kecil, dan Menengah

Peraturan OJK Nomor 35/POJK.05/2015 tentang Penyelenggaraan Usaha Modal Ventura,

Peraturan OJK Nomor 36/POJK.05/2015 tentang Tata Kelola Perusahaan yang baik bagi Perusahaan Modal Ventura

Peraturan OJK Nomor 37/POJK.05/2015 tentang Pemeriksaan Langsung Perusahaan Modal Ventura 